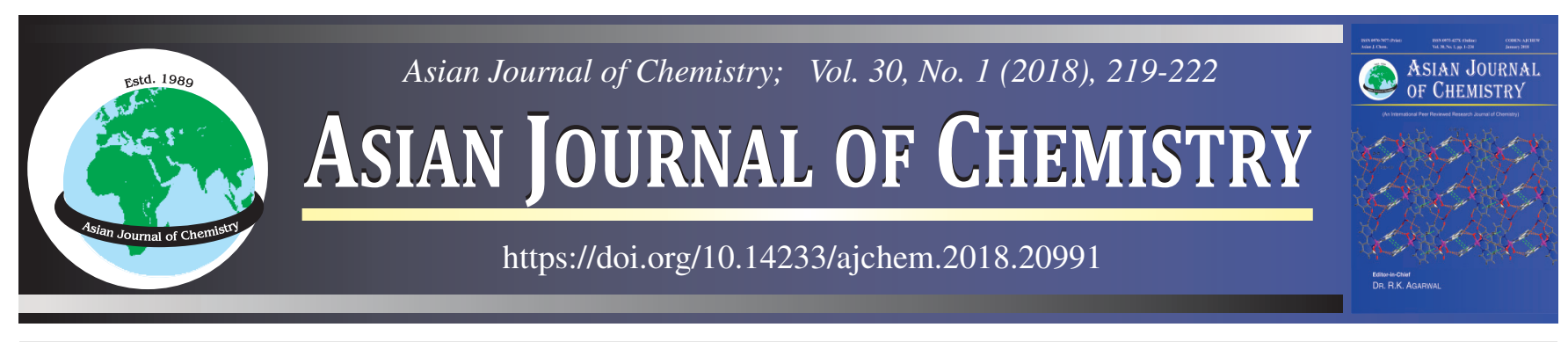

\title{
Air Pollution Tolerance Index to Assess the Pollution \\ Tolerance Level of Plant Species in Industrial Areas
}

\author{
Suvendu Kumar Dash ${ }^{1, *}$ and Aditya Kishore Dash ${ }^{2}$
}

${ }^{1}$ Department of Environmental Engineering, Institute of Technical Education and Research, Siksha 'O' Anusandhan University, Bhubaneswar751030, India

${ }^{2}$ Biofuel and Bioprocessing Research Centre, Institute of Technical Education and Research, Siksha 'O' Anusandhan University, Bhubaneswar751030, India

*Corresponding author: E-mail: suvendudash84@gmail.com

\begin{abstract}
The objective of the present research was to examine the air pollution tolerance index (APTI) of 20 plant species near an industrial complex. The highest APTI was calculated for plant Dalbergia sisoo (25.75) and the lowest was for Artocarpus sp. (11.40). Relative water content for different plant species varied between $52.45 \mathrm{mg} / \mathrm{g}$ (Artocarpus sp.) to $89.56 \mathrm{mg} / \mathrm{g}$ (Ailanthus excels) and pH between 3.49 (Pongamia pinnata) to 7.01 (Dalbergia sisoo). The chlorophyll content was found maximum in Mangifera indica (14.23 mg/g) and minimum in Eucalyptus sp. (5.34 mg/g). The highest ascorbic acid was recorded in Dalbergia sisoo (9.05 mg/g) and lowest in Gmelina arborea $(4.36 \mathrm{mg} / \mathrm{g})$. Further, both total chlorophyll and relative water contents were significantly correlated with APTI $(\mathrm{r}=0.7356$ and $\mathrm{r}$ $=0.8302$, respectively). It was calculated that there is no significant correlation of $\mathrm{pH}$ with APTI $(\mathrm{r}=0.1407)$, whereas ascorbic acid was significantly correlated with APTI $(r=0.8522)$. Present study provides a basic idea for screening and selecting plant species for plantation in industrial areas.
\end{abstract}

Keywords: Air pollution tolerance index (APTI), Ascorbic acid, Chlorophyll, Relative water content.

\section{INTRODUCTION}

Air pollution in urban areas is gradually becoming a great challenge. Now a day's industrialization and globalization are the key factor which causes serious air pollution problems [1]. Continuous increase in human population, increasing in road transportation, vehicular traffic and industrialization have resulted an increase in the concentration of gaseous and particulate matter in the atmosphere [2-6]. The overall physiology of plants has been affected due to the particulate matters and gaseous pollutants presence in the atmosphere beyond the threshold limit $[7,8]$. A number of publication are reported to evaluate the response of traffic load on plants [9]. The ability of plants to remove pollutants from the air and act as sink for air contaminates were explored [10]. Green plants has an important role to mitigate the air pollution is also well known [11] but urban developmental activities is replacing maximum vegetation areas with concrete buildings $[12,13]$. Gaseous pollutants such as sulfur dioxide, nitrogen dioxide, carbon monoxide and particulate matters released from combustion activities along with toxic metals, organic materials and radioactive isotopes goes to the atmosphere [14]. Plant absorbs $\mathrm{NO}_{2}$ which is assi- milated into nitrogenous compounds and utilizes as a major nutrient for its growth [15].

The leaf area of different plant provides a platform for absorption and accumulation of air pollutants which helps to minimize the pollution level in the environment $[16,17]$ which varied from species to species. In the present study air pollution tolerance index (APTI) has been calculated for 20 different plant species by synthesizing the values of different biochemical parameters such as ascorbic acid, relative water, chlorophyll and leaf extract $\mathrm{pH}$. Various studies on the APTI of plants for development of green belt have been conducted by many workers [18-20].

Rather than individual parameter the combination of all biochemical parameters gave a more reliable value to predict the tolerance of plant species towards different pollutants. By adopting this technique of choosing suitable species as a mitigation measure for air pollution, industrial areas could able to achieve the air quality standard [21-23].

\section{EXPERIMENTAL}

Leaf samples were collected from 20 different tree species from the study areas which were adjacent to the industrial and 
mining activities. For further analysis, leaf samples were collected, cleaned and then refrigerated at $22^{\circ} \mathrm{C}$ under suitable condition as per the standard procedures. The list of plants selected for the study with their scientific name and family are given in Table-1.

\begin{tabular}{|c|c|c|c|}
\hline \multicolumn{4}{|c|}{$\begin{array}{c}\text { TABLE-1 } \\
\text { LIST OF PLANTS STUDIED }\end{array}$} \\
\hline $\begin{array}{l}\text { S. } \\
\text { No. }\end{array}$ & $\begin{array}{l}\text { Common } \\
\text { name }\end{array}$ & Scientific name & Family \\
\hline 1 & Mango & Mangifera indica & Anacardiaceae \\
\hline 2 & Teak & Tectona grandis & Verbenaceae \\
\hline 3 & Peepal & Ficus religiosa & Moraceae \\
\hline 4 & Bela & Aegle marmelos & Rutaceae \\
\hline 5 & Kusum & Sghleichera oleosa & Sapindaceae \\
\hline 6 & Sal & Shorea robusta & Diplterocarpaceae \\
\hline 7 & Bamboo & Bambusa bamboos & Poaceae \\
\hline 8 & Panasa & $\begin{array}{l}\text { Artocarpus } \\
\text { hetterophyllus }\end{array}$ & Moraceae \\
\hline 9 & Margosa & Azadirachta indica & Meliaceae \\
\hline 10 & Krushnachuda & Delonix regia & Ceasal Pinaceae \\
\hline 11 & Guava & Psidium guajava & Myrtaceae \\
\hline 12 & Gumhari & Gmelina arborea & Verbenaceae \\
\hline 13 & Kendu & Diospyros melanoxylon & Ebenaceae \\
\hline 14 & Sishoo & Dalbergia sisoo & Fabeceae \\
\hline 15 & Karanja & Pongamia pinnata & Fabeceal \\
\hline 16 & Mahalimb & Ailanthus excels & Simarubaceae \\
\hline 17 & Gulmohar & Ceasal pinia & Ceasalpiniaceae \\
\hline 18 & Ashoka & Polyalthia longifolia & Annonaceae \\
\hline 19 & Jack fruit & Artocarpus sp. & Moraceae \\
\hline 20 & Eucalyptus & Eucalyptus sp. & Myrtaceae \\
\hline
\end{tabular}

\section{Analysis of different leaf parameters}

Ascorbic acid: Ascorbic acid also acts as an antioxidant which influences the plant's resistivity towards air pollution [24]. Ascorbic acid content (mg/g) was measured using the standard formula [25].

Total chlorophyll: Higher chlorophyll content has the potential to tolerate the concentrations of different pollutants.
Total chlorophyll content of the leaf samples were estimated as per the standard [26].

Leaf extract pH: It has been observed that the increasing level of leaf extract $\mathrm{pH}$ in plant leads to increase the tolerance level towards the air pollutants [27]. For $\mathrm{pH}$ measurement, $1 \mathrm{~g}$ of leaf sample was taken into a mortar and pestle and then homogenized with water. Finally, $20 \mathrm{~mL}$ of deionized water was added and allowed to settle for 15-20 min and then the $\mathrm{pH}$ was measured.

Relative water content: Relative water content is an indicator of water balances of a plant, because it expresses the absolute amount of water, which the plant requires to reach artificial full saturation [28]. Leaf samples were collected from the field and transported immediately to the laboratory. Leaf material $(10 \mathrm{~g})$ was taken and dried at $60-70^{\circ} \mathrm{C}$ in a properly ventilated hot air oven for a period of $3 \mathrm{~h}$. The weight of the leaf material was measured and the percentage of water content in the leaf material was calculated [29].

Air pollution tolerance index (APTI): The APTI was determined by calculating $\mathrm{pH}(\mathrm{P})$, ascorbic acid (A), total chlorophyll $(\mathrm{T})$ and relative water content $(\mathrm{R})$ of the leaf samples. The APTI was computed by using the given formula [30]:

$$
\mathrm{APTI}=\mathrm{A}(\mathrm{T}+\mathrm{P}) / 10
$$

\section{RESULTS AND DISCUSSION}

The relative water content, $\mathrm{pH}$, chlorophyll, ascorbic acid and APTI values for different plant species are given in Table-2.The relative water content varied between $52.45 \mathrm{mg} / \mathrm{g}$ (Artocarpus sp.) to $89.56 \mathrm{mg} / \mathrm{g}$ (Ailanthus excels). Higher amount of water is maintained the physiological balance in a plant body against the pollutants where the rate of transpiration iscomparatively high. The variation of relative water content is based on the atmospheric conditions, humidity and availability of moisture content in soil.

Leaf extract $\mathrm{pH}$ varied between 3.49 (Pongamia pinnata) to 7.01 (Dalbergia sisoo). $\mathrm{pH}$ plays a significant role in regulating

TABLE-2

BIOCHEMICAL PARAMETERS AND APTI VALUES FOR DIFFERENT PLANT SPECIES IN THE STUDY AREA

\begin{tabular}{|c|c|c|c|c|c|c|}
\hline S. No. & Scientific name & $\begin{array}{c}\text { Relative water } \\
\text { content }(\%)\end{array}$ & $\mathrm{pH}$ of leaf extracts & $\begin{array}{c}\text { Chlorophyll } \\
\text { content (mg/g) }\end{array}$ & $\begin{array}{l}\text { Ascorbic acid } \\
\text { content }(\mathrm{mg} / \mathrm{g})\end{array}$ & APTI \\
\hline 1 & Mangifera indica & 78.65 & 6.85 & 14.23 & 7.69 & 24.08 \\
\hline 2 & Tectona grandis & 64.61 & 5.92 & 12.56 & 6.43 & 18.34 \\
\hline 3 & Ficus religiosa & 79.69 & 5.12 & 11.53 & 8.92 & 22.82 \\
\hline 4 & Aegle marmelos & 81.25 & 4.98 & 10.96 & 6.13 & 17.90 \\
\hline 5 & Sghleichera oleosa & 79.21 & 6.06 & 13.41 & 6.99 & 21.53 \\
\hline 6 & Shorea robusta & 73.98 & 4.93 & 12.98 & 7.98 & 21.69 \\
\hline 7 & Bambusa bamboos & 64.76 & 6.21 & 8.69 & 7.56 & 17.74 \\
\hline 8 & Artocarpus hetterophyllus & 85.61 & 5.23 & 12.98 & 8.65 & 24.31 \\
\hline 9 & Azadirachta indica & 75.62 & 5.23 & 11.96 & 8.56 & 22.28 \\
\hline 10 & Delonix regia & 72.26 & 5.36 & 13.36 & 5.98 & 18.42 \\
\hline 11 & Psidium guajava & 80.23 & 6.01 & 12.58 & 9.01 & 24.77 \\
\hline 12 & Gmelina arborea & 69.75 & 3.68 & 11.69 & 4.36 & 13.68 \\
\hline 13 & Diospyros melanoxylon & 73.24 & 5.89 & 11.57 & 8.72 & 22.55 \\
\hline 14 & Dalbergia sisoo & 83.56 & 7.01 & 12.21 & 9.05 & 25.75 \\
\hline 16 & Ailanthus excels & 89.56 & 6.02 & 13.97 & 7.89 & 24.73 \\
\hline 17 & Ceasal pinia & 76.35 & 4.92 & 10.83 & 5.74 & 16.68 \\
\hline 18 & Polyalthia longifolia & 62.34 & 6.02 & 7.24 & 7.64 & 16.36 \\
\hline 19 & Artocarpus sp. & 52.45 & 6.32 & 6.92 & 4.65 & 11.40 \\
\hline 20 & Eucalyptus sp. & 57.83 & 6.89 & 5.34 & 6.53 & 13.77 \\
\hline
\end{tabular}


$\mathrm{SO}_{2}$ sensitivity of plants. The plant's tolerance level is directly proportional to the higher level of leaf extract $\mathrm{pH}$ which helps a plant to sustain in polluted conditions. The importance of $\mathrm{pH}$ in mediating physiological responses to stress was another reason for including it in APTI component [31].

Chlorophyll content depends on the rate of photosynthesis and the amount of nutrient available in the soil [32]. Chlorophyll was found to be maximum in Mangifera indica $(14.23 \mathrm{mg} / \mathrm{g})$ and minimum in Eucalyptus sp. (5.34 mg/g). Leaf chlorophyll changes can serve as relative indicators of environmental quality [33].

Ascorbic acid acts as a strong reluctant and it activates several physiological and defense characteristics in the plant [34]. The highest ascorbic acid was recorded in Dalbergia sisoo (9.05 mg/g) and lowest in Gmelina arborea (4.36 mg/g). The APTI values were recorded highest in Dalbergia sisoo (25.75) and lowest in Artocarpus sp. (11.40). Low APTI values were generally sensitive to air pollutants and vice-versa. Air pollution tolerance index provides an idea for screening or selecting of plants for their efficiency as well as susceptibility to different air pollutants. From the above results, it was observed that out of 20 plant species, 5 species belongs to sensitivity category and 15 species belongs to intermediate category, when compared with the standard APTI value.

Further, a correlation matrix among different parameters along with APTI has been calculated and shown in Table-3. There is a significant correlation between chlorophyll content and relative water content with APTI value $(r=0.7356$ and $r=$ 0.8302). There is no significant correlation of $\mathrm{pH}$ with APTI, whereas ascorbic acid was significantly correlated with APTI $(\mathrm{r}=0.8522)$. Hence, APTI value has a strong and positive correlation with total chlorophyll, relative water content and ascorbic acid. This indicates that concentrations of different parameters like total chlorophyll, relative water content, $\mathrm{pH}$ and ascorbic acid influence the APTI value $[35,36]$.

TABLE-3

CORRELATIONCOEFFICIENT OF PARAMETERS STUDIED

\begin{tabular}{lccccc}
\hline & $\begin{array}{c}\text { Total } \\
\text { chlorophyll }\end{array}$ & RWC & pH & AA & APTI \\
\hline $\begin{array}{l}\text { Total } \\
\text { chlorophyll }\end{array}$ & 1 & & & & \\
RWC & $0.7885^{* *}$ & 1 & & & \\
pH & -0.2392 & -0.2068 & 1 & & \\
AA & 0.3290 & 0.5463 & 0.19006 & 1 & \\
APTI & $0.7356^{* *}$ & $0.8302^{* *}$ & 0.14078 & $0.8522^{* *}$ & 1 \\
\hline
\end{tabular}

**Correlation (r) is strong and significant; $\mathrm{RWC}=$ Relative water content; $\mathrm{AA}=$ Ascorbic acid.

Figs. 1-3 show the correlation graph of APTI with total chlorophyll, relative water content and ascorbic acid content.

\section{Conclusion}

Determination of air pollution tolerance index (APTI) value is an useful technique to trace the tolerance and susceptibility of different species towards air pollution. The present study revealed that different plants respond differently to air pollution. Therefore biomonitoring is an important tool to find out the impact of air pollution on different plant species particularly in industrial areas. To fulfill the concept of green-belt

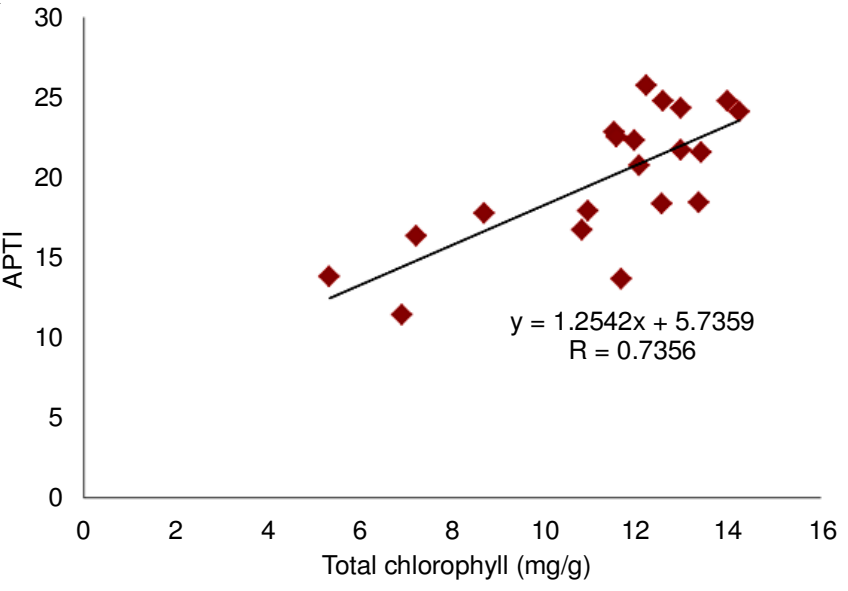

Fig. 1. Correlation between total chlorophyll and APTI

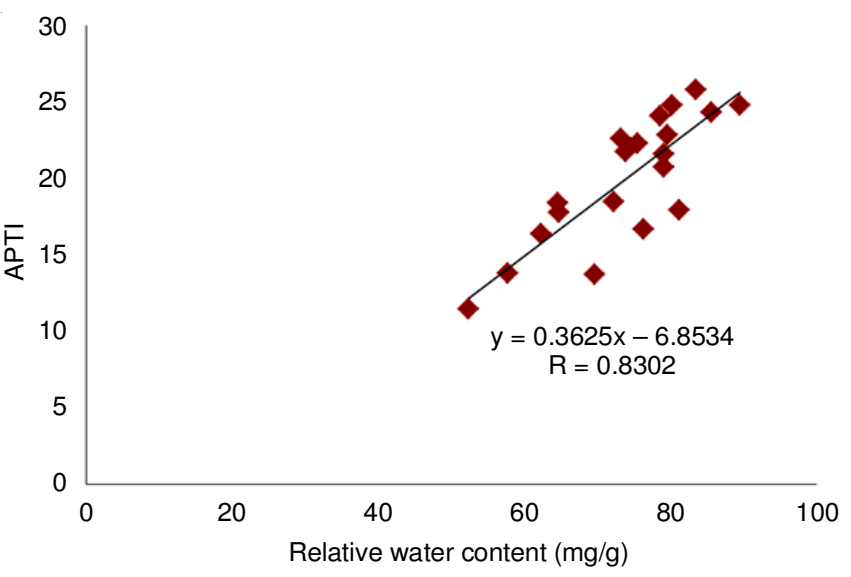

Fig. 2. Correlation between relative water content and APTI

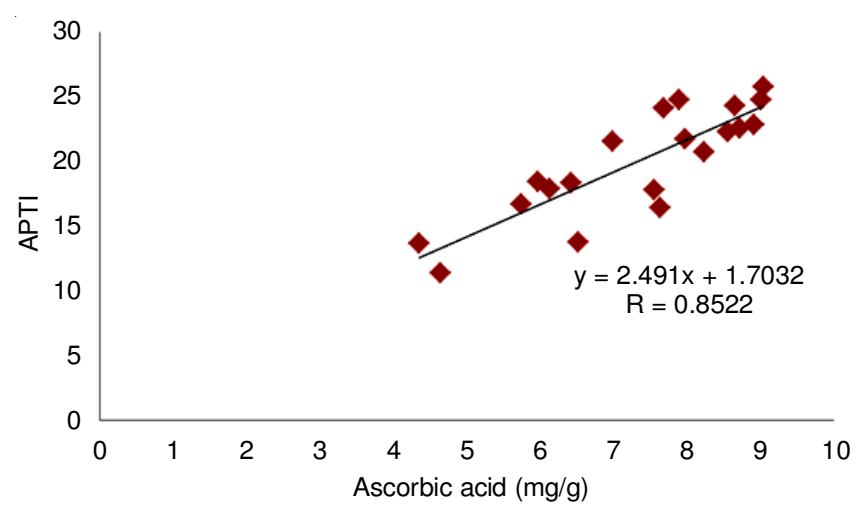

Fig. 3. Correlation between ascorbic acid and APTI

development programme, plants with high APTI values are recommended which are potential to grow under air pollution condition. The present research revealed the efficiency of some selected plant species for plantation near industrial areas to minimize the ambient air pollution load.

\section{REFERENCES}

1. L.S. Vailshery, M. Jaganmohan and H. Nagendra, Urban Forest Urban Green., 12, 408 (2013); https://doi.org/10.1016/i.ufug.2013.03.002.

2. P.O. Agbaire and E. Esiefarienrhe, J. Appl. Sci. Environ. Manage., 13, 11 (2009); https://doi.org/10.4314/jasem.v13i1.55251. 
3. D. Sahoo, A.K. Dash and S.K. Sahu, Int. J. Eng. Sci. Res. Technol., 6, 429 (2017).

4. S.K. Dash and A.K. Dash, Pollut. Res., 34, 181 (2015).

5. S.K. Dash and A.K. Dash, Indian J. Sci. Technol., 8, 1 (2015); https://doi.org/10.17485/ijst/2015/v8i35/81468.

6. A.K. Dash, S.K. Sahu, A. Pradhan, S.K. Dash and R.N. Kolli, Asian J. Chem., 29, 1150 (2017); https://doi.org/10.14233/ajchem.2017.20477.

7. T.W. Ashenden and I.A.D. Williams, Environ. Pollut., 21, 131 (1980); https://doi.org/10.1016/0143-1471(80)90041-0.

8. V. Mejstrik, Environ. Pollut., 21, 73 (1980); https://doi.org/10.1016/0143-1471(80)90034-3.

9. P.G. Angold, J. Appl. Ecol., 34, 409 (1997) https://doi.org/10.2307/2404886.

10. A.K. Tripathi and M. Gautam, J. Environ. Biol., 28, 127 (2007).

11. M.N. Islam, K.S. Rahman, H.M. Bahar, M.A. Habib, K. Ando and N. Hattori, Urban Forest Urban Green., 11, 460 (2012); https://doi.org/10.1016/j.ufug.2012.06.004.

12. A. Onishi, X. Cao, T. Ito, F. Shi and H. Imura, Urban Forest Urban Green., 9, 323 (2010); https://doi.org/10.1016/j.ufug.2010.06.002

13. H. Sugawara and T. Takamura, Boundary-Layer Meteorol., 153, 539 (2014); https://doi.org/10.1007/s10546-014-9952-0.

14. T. Bhattacharya, L. Kriplani and S. Chakraborty, Univ. J. Environ. Res. Technol., 3, 199 (2013).

15. Sulistijorini, Z.A. Mas'ud, N. Nasrullah, A. Bey and S. Tjitrosemito, Hayati J. Biosci., 15, 123 (2008); https://doi.org/10.4308/hjb.15.3.123.

16. F.J. Escobedo, J.E. Wagner, D.J. Nowak, C.L. De la Maza, M. Rodriguez and D.E. Crane, J. Environ. Manage., 86, 148 (2008); https://doi.org/10.1016/j.jenvman.2006.11.029.

17. A. Garg, P. Saxena and C. Ghosh, Int. J. Sci. Technol. Res., 4, 199 (2015).

18. M. Govindaraju, R.S. Ganesh Kumar, V.R. Muthukumaran and P. Visvanathan, Environ. Sci. Pollut. Res. Int., 19, 1210 (2012); https://doi.org/10.1007/s11356-011-0637-7.

19. A. Gholami, A. Mojiri and H. Amini, J. Anim. Plant Sci., 26, 475 (2016).
20. K. Navjot, S. Simpy and N.C. Gupta, Int. J. Curr. Sci., 19, 181 (2016).

21. K. De Ridder, V. Adamec, A. Bañuelos, M. Bruse, M. Bürger, O. Damsgaard, J. Dufek, J. Hirsch, F. Lefebre, J.M. Pérez-Lacorzana, A. Thierry and C. Weber, Sci. Total Environ., 334-335, 489 (2004); https://doi.org/10.1016/j.scitotenv.2004.04.054.

22. A. Lee and R. Maheswaran, J. Public Health (Bangkok), 33, 212 (2011); https://doi.org/10.1093/pubmed/fdq068.

23. R.N. Lohe, B. Tyagi, V. Singh, P. Kumar Tyagi, D.R. Khanna and R.A. Bhutiani, Global J. Environ. Sci. Manage., 1, 315 (2015).

24. Y.J. Liu and H. Ding, WSEAS Trans. Environ. Dev., 4, 24 (2008).

25. A. Begum and S. Harikrishna, E-J. Chem., 7(S1), S151 (2010); https://doi.org/10.1155/2010/398382.

26. D.I. Arnon, Plant Physiol., 24, 1 (1949); https://doi.org/10.1104/pp.24.1.1.

27. C.S. Chaudhary and D.N. Rao, Proc. Indian Natl. Sci. Acad., 43, 236 (1977).

28. D.N. Sen and M.C. Bhandari, ed.: A.M. Althawadi, Ecological and Water Relation to Two Citrullus spp., In: Indian Arid Zone, Environmental Physiology and Ecology of Plants, pp. 203-228 (1978).

29. G. Klumpp, C.M. Furlan, M. Domingos and A. Klumpp, Sci. Total Environ., 246, 79 (2000); https://doi.org/10.1016/S0048-9697(99)00453-2.

30. S.K. Singh and D.N. Rao, Proceedings of International Symposium on Air Pollution Control, IIT, Delhi, India, pp. 218-224 (1983).

31. K. Arunpandiyan, S. Malathy and F. Mujeera, Int. J. Educ. Sci. Res., 5, 33 (2016).

32. J.N.B. Bell and C.H. Mudd, ed.: T.A. Mansfield, Effects of Air Pollutants on Plants, Cambridge University Press, London, pp. 87-103 (1976).

33. G.A. Carter and A.K. Knapp, Am. J. Bot., 88, 677 (2001); https://doi.org/10.2307/2657068.

34. T. Keller and H. Schwager, Eur. J. Forest Pathol., 7, 338 (1977); https://doi.org/10.1111/j.1439-0329.1977.tb00603.x.

35. M.U. Beg, M. Farooq, S.K. Bhargava, M.M. Kidwai and M.M. Lal, Environ. Ecol., 8, 791 (1990).

36. A. Chauhan, New York Sci. J., 3, 45 (2010); https://doi.org/10.7537/marsnys030210.08. 